\title{
Perancangan Museum Seni dan Musik Interaktif Berbasis Perilaku Belajar
}

\author{
Rahmi Hadiyanti dan Arina Hayati \\ Departemen Arsitektur, Fakultas Arsitektur, Desain dan Perencanaan, \\ Institut Teknologi Sepuluh Nopember (ITS) \\ e-mail: arina_h@arch.its.ac.id
}

\begin{abstract}
Abstrak-Perancangan museum seni dan musik interaktif berbasis perilaku belajar, dilatarbelakangi dengan merespon sebuah fenomena untuk meningkatkan ketertarikan masyarakat terhadap museum. Museum sebagai salah satu fasilitas yang menyediakan informasi untuk mendukung budaya belajar masyarakat. Sebuah museum interaktif dapat menjadi tempat menarik bagi semua kalangan masyarakat, khususnya anak-anak dan usia produktif. Namun, saat ini museum dengan konsep interaktif masih sedikit di Indonesia, terutama Surabaya. Perancangan museum seni dan musik interaktif ini bertujuan mewadahi minat masyarakat yang mencari informasi dan pengetahuan di sekitar mereka. Pendekatan perancangan yang digunakan adalah arsitektur perilaku, melalui hubungan persepsi, aksi, dan reaksi seseorang dalam ruang arsitektur; didukung pendekatan romantika dan penerapan tematik. Hasil rancangan museum seni dan musik interaktif, dieksplorasi berdasarkan aspek formal (site plan, program ruang dan sirkulasi, suasana, dan bentuk bangunan), dan secara teknis (struktur dan pencahayaan ruang).
\end{abstract}

Kata Kunci - Interaktif; Museum; Perilaku Belajar; Seni dan Musik

\section{PENDAHULUAN}

$\mathrm{P}$ ADA perancangan ini, penulis mengamati kurangnya antusias masyarakat dalam budaya belajar atau kebiasaan belajar. Seseorang tidak terbiasa belajar dan menganggap belajar sebagai hal membosankan dan bersifat formal. Hal tersebut disebabkan oleh faktor eksternal yaitu cara penyampaian, bentuk fasilitas, dan kemonotonan pada proses keberlangsungannya. Selain itu, belajar hanya dianggap identik suasana formal dan bangku sekolah. Adanya pemahaman ini, memberikan dampak pada beberapa fasilitas belajar yang telah disediakan oleh pihak pemerintah tidak dimanfaatkan secara maksimal oleh masyarakat.

Merespon fenomena tersebut, salah satu usaha pemerintah adalah menyediakan ruang publik seperti perpustakaan, sekolah alam, taman baca atau museum untuk menjadi sarana belajar diluar konteks sekolah. Museum adalah salah satu fasilitas yang berpotensi untuk mengeksplorasi ruang, mendapatkan informasi dan pengetahuan akan suatu hal tertentu. Sebagian besar museum di Indonesia dianggap tidak menarik dan membosankan, sehingga menyebabkan kurangnya minat masyarakat berkunjung. Melalui kebutuhan ruang interaktif, maka sebuah museum tidak hanya menyediakan berbagai kebutuhan formal seperti memajang dan menyimpan

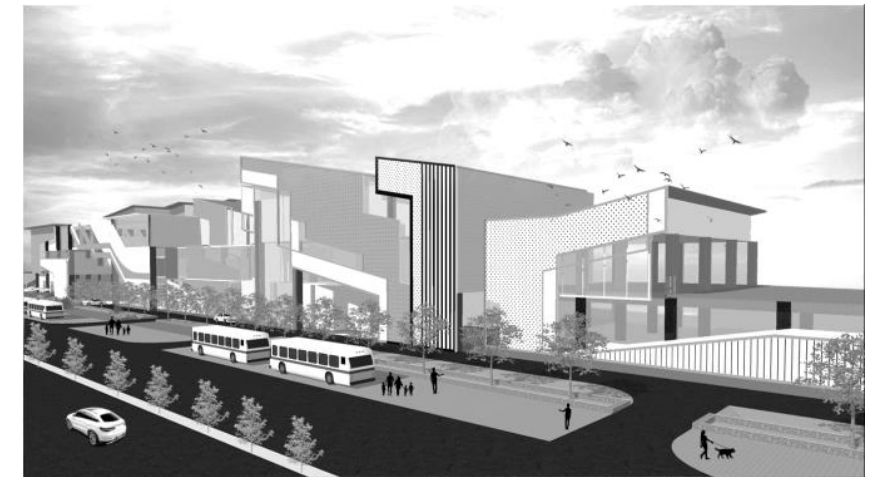

Gambar 1. Hasil Rancangan Museum Seni dan Musik Interaktif.

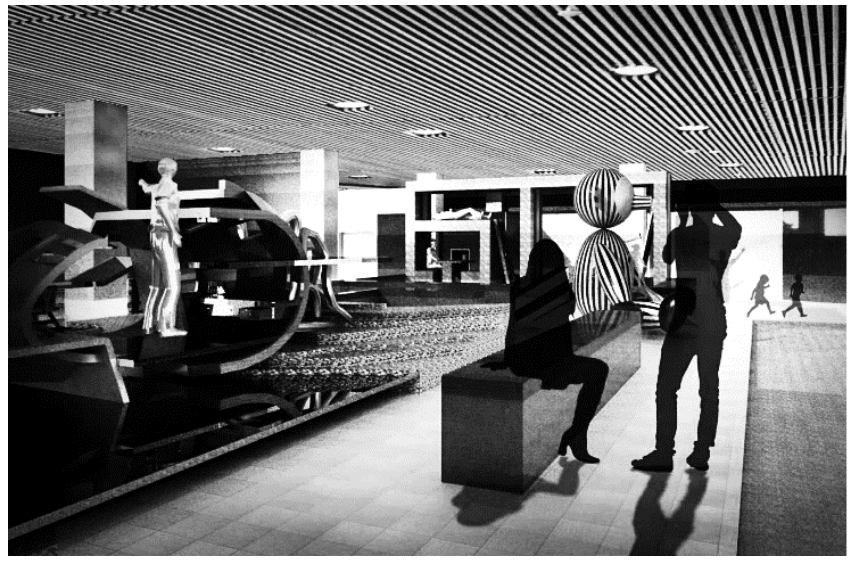

Gambar 2. Suasana Ruang Museum Seni

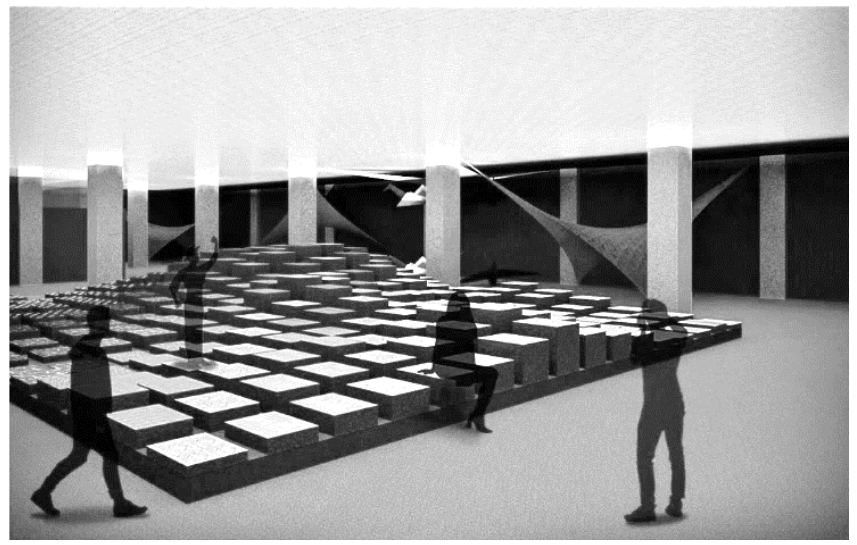

Gambar 3. Suasana Ruang Museum Seni dengan Integrasi Interaktif. 
benda tertentu, tetapi juga dapat memicu pengunjung agar lebih interaktif dalam mengeksplorasi museum. Dengan demikian, perancangan museum seni dan musik ini memiliki tema interaktif dengan pendekatan perilaku belajar. Perilaku belajar tersebut dianalisa dari konteks pengguna dan kondisi lingkungan melalui observasi dan studi literatur.

\section{KONTEKS DESAIN}

Perancangan ini menganalisa seluruh aspek yang mendukung hasil desain dengan menentukan konteks pada desain. Konteks memberikan batasan tertentu pada desain sehingga dapat tepat sasaran. Konteks tersebut diantaranya adalah konteks kawasan, konteks pengguna, dan konteks rancangan.

\section{A. Konteks Kawasan}

Perancangan ini memerlukan lahan pada kawasan dengan kriteria sebagai berikut:

- Berada di area tengah kota dengan kondisi lingkungan yang beragam.

- Berada pada area dengan keberagaman aktivitas.

- Lingkungan memiliki potensi ruang publik dengan jumlah pengunjung yang tinggi.

- Pembagian zona secara makro pada kawasan mempertimbangkan komposisi ruang terbuka dan area masif (Gambar 4).

Melalui kriteria kawasan tersebut, maka dipilih kawasan terminal Joyoboyo. Kawasan tersebut merupakan area komersil, pemukiman, dan fasilitas umum yang didominasi oleh tingginya Mobile Multiculture (Gambar 5). Namun demikian, kawasan ini memiliki kondisi yang kurang baik, yaitu terdapat pemukiman kumuh (Gambar 6).

\section{B. Konteks Pengguna}

Perancangan dengan konsep perilaku belajar biasanya identik dengan pengguna anak-anak usia sekolah dan usia produktif. Namun, pengguna pada perancangan ini meliputi seluruh kalangan yang mendukung dan mendapatkan suasana belajar. Pengguna dapat memunculkan persepsi mereka sesuai dengan usia dan kebutuhan beraktivitas mereka dalam sebuah museum untuk mencari informasi dan belajar ilmu pengetahuan (Tabel 1).

Tabel 1.

Konteks Pengguna dan Respon Desain

\begin{tabular}{cc}
\hline \hline Segmen Pengguna & Respon \\
\hline Anak Jalanan & Objek tidak asing dan mudah diakses \\
Anak-anak umum & Objek menyediakan ruang aktivitas sesuai usia \\
Remaja/pemuda & Objek adalah inovasi eksplorasi proses belajar \\
Dewasa & Objek merupakan ruang publik iteraktif \\
Lansia & Obejk merupakan ruang pembangkit memori \\
Kesimpulan: melalui segmen pengguna yang demikian maka dapat \\
diperoleh kriteria desain yang mampu merespon capaian segmen. \\
\hline \hline
\end{tabular}

\section{Konteks Perancangan}

Setelah menganalisa dua konteks sebelumnya, maka menghasilkan perancangan dengan kriteria desain sebagai berikut:

a. Museum mampu mempertahankan identitas tipe museum namun tidak monoton yaitu melalui eksplorasi program ruang dan fasad (Gambar 7).

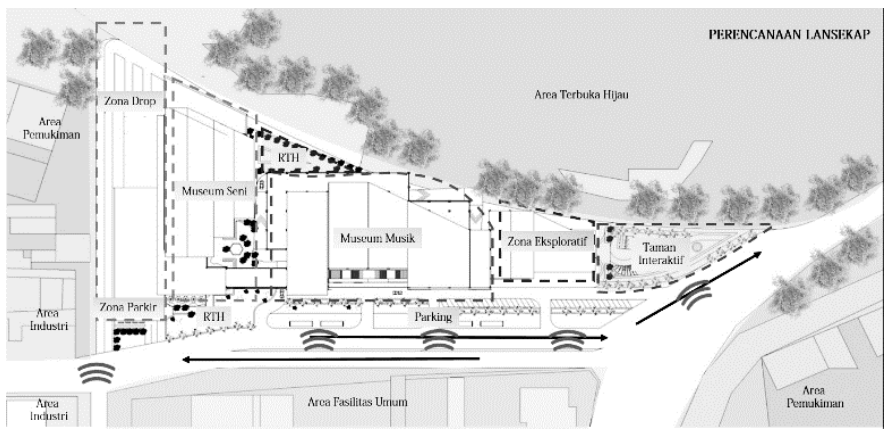

Gambar 4. Komposisi Pembagian Zona Makro

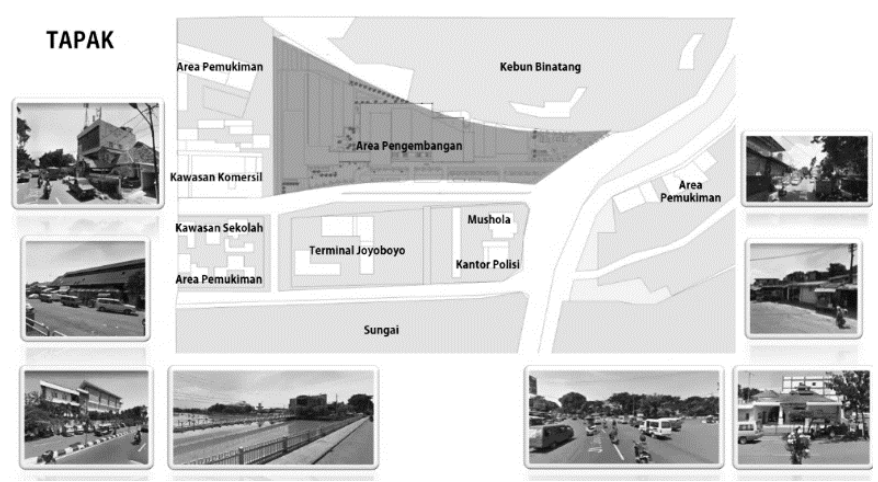

Gambar 5. Deskripsi Kawasan Terminal Joyoboyo

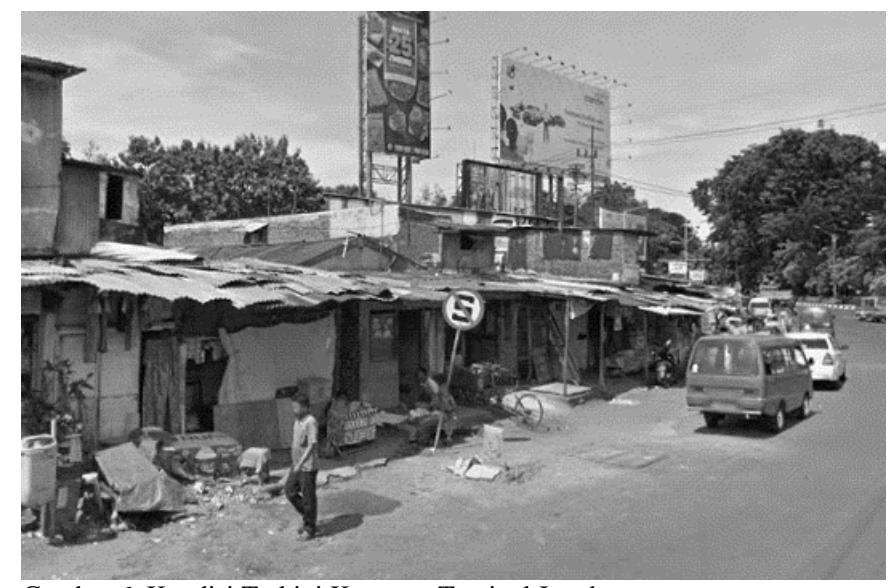

Gambar 6. Kondisi Terkini Kawasan Teminal Joyoboyo

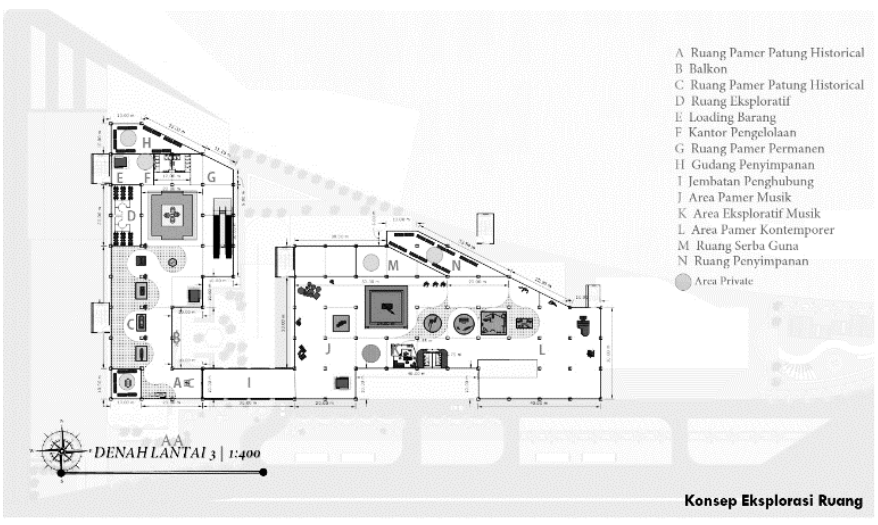

Gambar 7. Eksplorasi Program Ruang. 
b. Museum menampung aktivitas belajar interaktif yang direspon dengan program dan organisasi ruang yang di susun secara tematik.

c. Konsep tematik menyesuaikan dengan kondisi dan potensi lingkungan

d. Ruang publik museum memiliki tingkat fleksibilitas tinggi untuk mendukung prinsip berkelanjutan.

\section{PENDEKATAN DAN METODE PERANCANGAN}

Pendekatan utama yang digunakan dari perancangan ini adalah pendekatan Perilaku. Konsep perilaku tersebut memiliki kaitan erat antara manusia dan hubungannya dengan suatu lingkungan fisik. Dengan kata lain, apabila terdapat perubahan lingkungan yang disesuaikan dengan suatu kegiatan, maka akan ada pengaruh terhadap perilaku manusia [1]. Pendekatan lain yang digunakan selain perilaku adalah pendekatan romantika yaitu, cara penyajian benda-benda koleksi disusun sehingga dapat mengungkapkan suasana tertentu yang berhubungan dengan benda-benda yang dipamerkan. Pendekatan ini memberikan dampak yang jelas pada suasana yang dicapai.

Metode yang dipilih untuk mencapai pendekatan perilaku adalah melalui pemrograman dengan penelusuran dan analisis masalah [2]. Pemrograman merupakan alat untuk berkomunikasi dan juga sebagai metoda pengambilan keputusan, sehingga pemrograman merupakan sistem dari proses desain [3]. Perilaku selalu berhubungan dengan lingkungan dimana ia berada. Sebagai contoh, perilaku pengguna disebuah ruang akan memberikan gambaran pola perilaku yang diterjemahkan melalui peta perilaku pada ruang tersebut. Pemetaan ini dibantu dengan analisa diagram sirkulasi (Gambar 8) dan diagram planimetrik (Gambar 9). Dengan peta perilaku ini membantu pengguna dalam menterjemahkan setting aktifitas pada ruang. Pemrograman rancangan fasilitas selalu terkait dengan ruang, sehingga perilaku pengguna merupakan unsur yang cukup besar mempengaruhi pemrograman tersebut. Andrew Chaplin mencoba menjelaskan tentang metode program dalam sebuah proses desain dapat dilakukan untuk mencapai desain sesuai dengan sasaran [4].

\section{IV.HASIL PERANCANGAN}

Secara formal dan teknis, perancangan menghasilkan museum dengan konsep belajar interaktif yang menghadirkan tatanan massa fleksibel yang dapat menampung keragaman aktivitas publik. Proses perancangan dilakukan dari pembagian zona secara spesifik, tatanan masa yang memenuhi respon lingkungan, sistem sirkulasi yang membantu program aktivitas, program ruang yang menginterpretasikan konsep, serta eksplorasi formal lainnya dan eksprolasi teknis terintegrasi yang mendukung tercapainya rancangan.
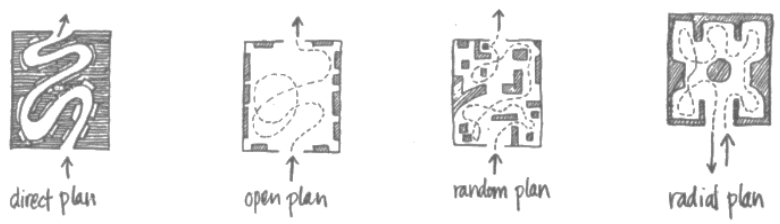

Gambar 8. Pola Sirkulasi Variasi Ruang dalam Museum

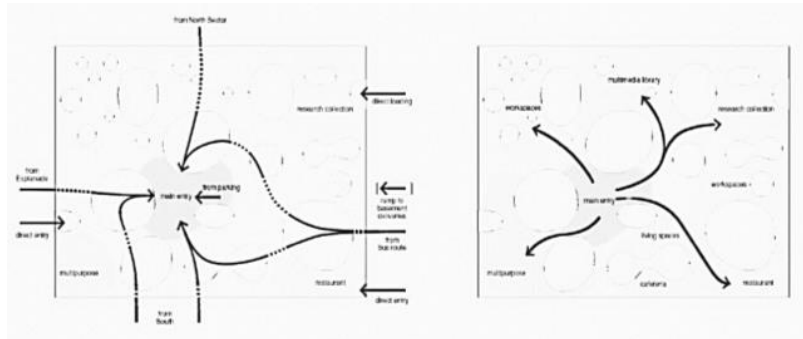

Gambar 9. Diagram Planimetrik sebagai Proses Iterasi Desain

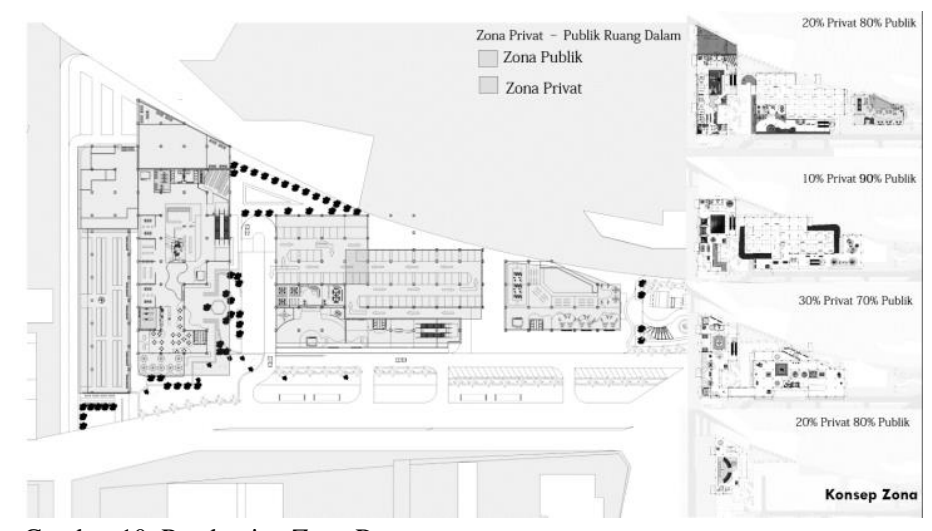

Gambar 10. Pembagian Zona Ruang

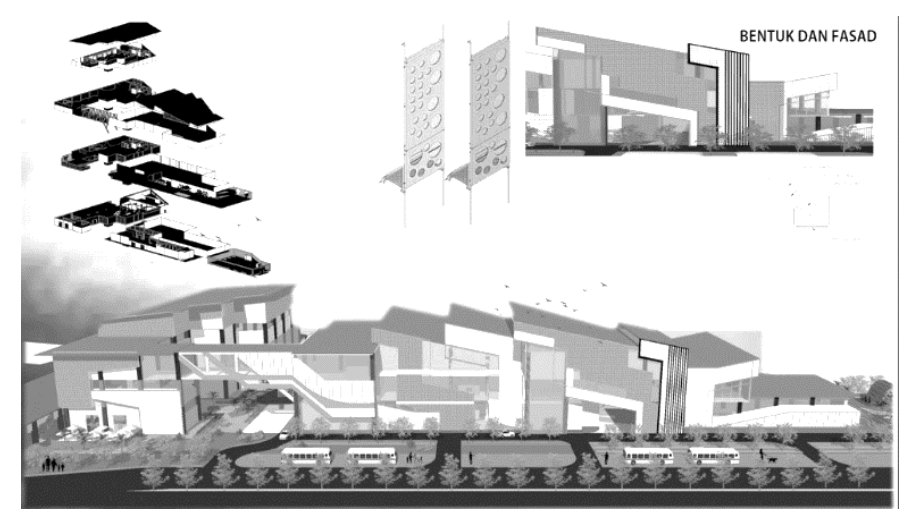

Gambar 11. Eksplorasi Formal (Tatanan Massa dan Ekspresi Fasad) 


\section{A. Pembagian Zona}

Pembagian zona dalam desain ini terbagi menjadi empat zona berdasarkan kehadiran aktivitas publik dan keberadaan benda koleksi. Zona pertama yaitu zona publik - tanpa koleksi. Zona kedua adalah zona publik - dengan koleksi. Zona ketiga adalah zona non publik - tanpa koleksi dan zona keempat adalah zona penyimpanan koleksi. (Gambar 10)

\section{B. Tatanan Massa}

Penataan massa dilakukan berdasarkan pengaruh dari orientasi bangunan, fungsi, dan estetika [5]. Berdasarkan pengaruh orientasi jalan terhadap massa bangunan, maka penataan tinggi massa di rancang berbeda untuk memenuhi kebutuhan jarak pandang. Berdasarkan fungsi tematik, lantai terbagi menjadi 4 layer untuk mewadahi kebutuhan organisasi ruang yang telah ditentukan. Secara estetika, pengelolaan fasad menyesuaikan tema interaktif museum (Gambar 11)

\section{Sirkulasi dan Program Aktivitas}

Program aktivitas dibagi menjadi 2 bagian, yaitu:

\section{a. Aktivitas Pimer}

Sesuai dengan fungsi museum, maka aktivitas utamanya adalah untuk menikmati barang koleksi, belajar, berinteraksi, dan mengeksplorasi segala sesuatu yang disajikan di dalam museum. Sehingga, tujuan belajar interaktif dapat tercapai melalui penyediaan fasilitas dan hasil aktivitas.

b. Aktivitas Sekunder

Sebagai fasilitas publik, maka penyediaan fungsi pendukung dihadirkan sebagai wadah aktivitas sekunder untuk pendukung fungsi utama. Aktivitas sekunder secara spesifik mencakup segala sesuatu yang berhubungan dengan fungsi utama dan pendukung. Kegiatan eventual, kegiatan eksplorasi, dan kebutuhan pribadi perlu disediakan secara selaras dengan fungsi utama. Secara teknis, hasil perancangan menghasilkan ruangruang fleksibel dan integrasi teknis melalui utilitas dan struktur. Keseluruhan sistem teknis adalah sistem pendukung berdirinya perancangan dan pencapaian tujuan perancangan serta aktivitas manusia didalamnya [6].

Penataan sirkulasi dapat dilakukan pada ruang luar dan ruang dalam museum. Pada ruang luar, sirkulasi kendaraan dipisahkan antara jalur publik dan jalur khusus. Selain itu, sirkulasi pejalan kaki disediakan melalui sistem perkerasan untuk mengarahkan pengunjung (Gambar 12). Sistem sirkulasi dalam ruang museum ditentukan oleh aktivitas dan program ruang. Penataan sirkulasi dirancang secara naratif agar pengunjung terarah pada setiap ruang yang dihadirkan. Salah satu contoh adalah penggunaan material pada lantai dan hadirnya suasana tertentu pada sebuah ruang.

Berbagai ruang publik (selain ruang pamer) dirancang sebagai respon keragaman aktivitas publik. Secara tematik, seni dan musik ditata pada ruang museum untuk menarasikan informasi dan pesan yang disampaikan dalam museum. Tujuannya adalah agar pengunjung dapat merasakan fungsi museum yang interaktif dan eksploratif.

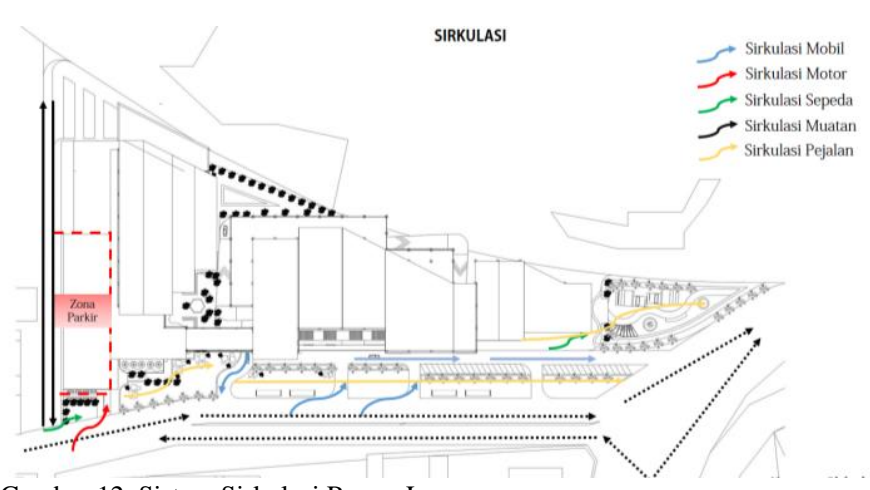

Gambar 12. Sistem Sirkulasi Ruang Luar

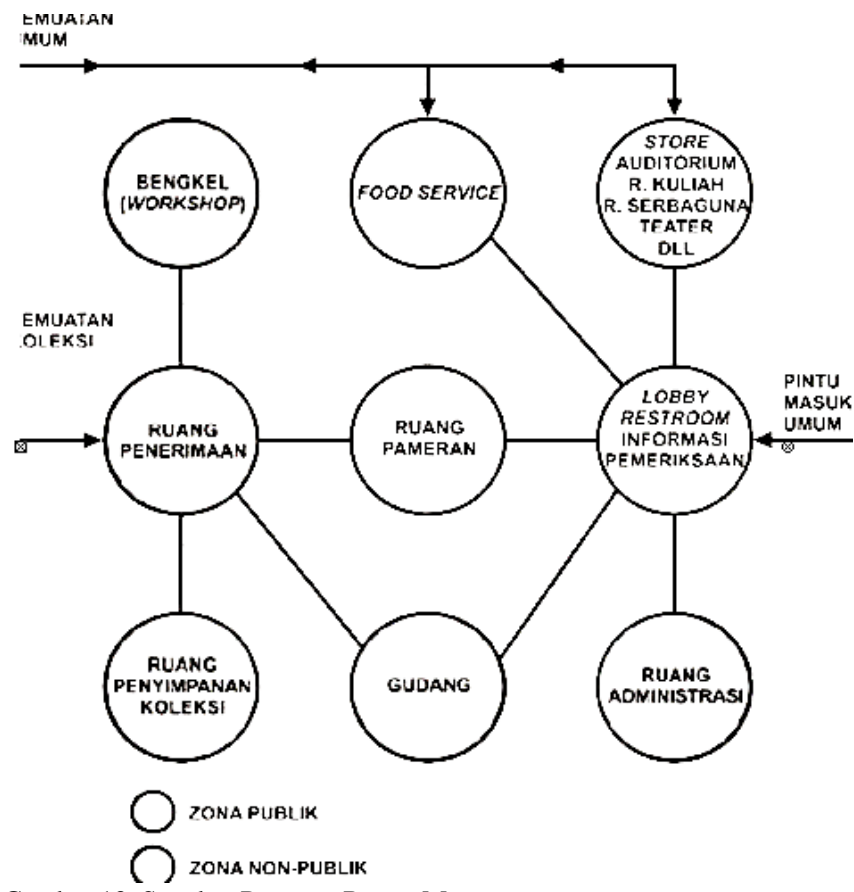

Gambar 13. Standart Program Ruang Museum

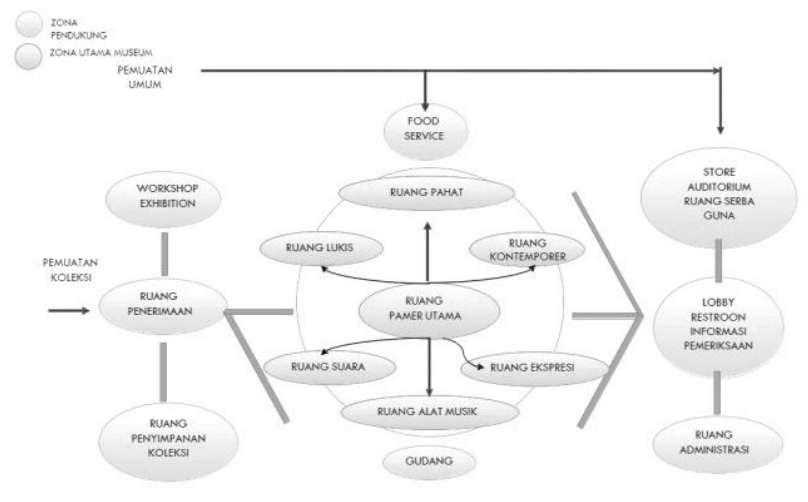

Gambar 14. Eksplorasi Program Ruang (Konsep Interaktif) 


\section{Program Ruang}

Sesuai standart, program ruang telah ditetapkan sesuai dengan kebutuhan aktivitas dan pengelolaan museum (Gambar 13). Organisasi ruang pada museum yang terbagi menjadi lima zona/area berdasarkan aktivitas publik dan keberadaan koleksi/pajangan. Zona-zona tersebut antara lain, zona publik tanpa koleksi, zona publik - dengan koleksi, zona non publik tanpa koleksi, zona non publik - dengan koleksi, dan zona penyimpanan koleksi. Dimensi ruang dikembangkan sesuai dengan kebutuhan museum, konsep rancang, dan kapasitas pengunjung.

Selanjutnya, program ruang dieksplorasi sesuai standart ruang museum yaitu ruang interaktif yang lebih spesifik. Sesuai dengan tema seni dan musik, maka untuk mencapai konsep Interaktif - Eksploratif, perlu adanya penyediaan ruang khusus untuk meningkatkan kualitas museum (Gambar 14).

\section{E. Eksplorasi Eksterior dan Interior}

Eksploasi untuk Fasad bangunan, konsep olahan geometri dirancang menarik dengan penggunaan warna tertentu. Karena konsekuensi kebutuhan perteduhan, maka tatanan masa dirancang memiliki kedalaman berbeda. Sedangkan kesan fasad masif dan transparan adalah konsekuensi kebutuhan pencahayaan, serta ekspose dan cladding adalah konsekuensi konsep estetika. Untuk mencapai suasana teduh dan mengurangi kepadatan kawasan, maka area hijau diperluas dan memberikan beberapa fasilitas ruang terbuka. Eksplorasi Interior Tematik Seni dan Musik, dirancang sesuai dengan jenis benda koleksi (Gambar 15).

\section{F. Eksplorasi Teknis}

Secara teknis, bangunan ini menggunakan integrasi antara struktur dan utilitas tertentu untuk mencapai fleksibilitas ruang. Struktur utama bangunan adalah penggunaan kolom (komposit) dan balok (baja). Selain itu, kebutuhan ruang sebuah museum terhadap jumlah pengunjung yang besar dalam satu waktu, disediakan ruang-ruang dengan luasan yang besar (Gambar 16). Eksplorasi material juga diterapkan sebagai sarana komunikasi konsep dan perwujudan suasana ruang. Material masif dengan bahan tertentu digunakan sesuai tematik ruang (Gambar 17).

Sistem utilitas juga mendukung aktivitas dalam ruang. Penghawaan buatan digunakan pada ruang-ruang publik, khususnya pada ruang pameran dimana suhu udara dan kelembaban dijaga agar tetap sesuai dengan kondisi perabot atau material koleksi (Gambar 18). Keseluruhan sistem teknis ini mendukung perancangan yang mewadahi aktivitas pengguna di dalamnya.

\section{KESIMPULAN}

Perancangan ini dilatarbelakangi oleh pemikiran mengenai rendahnya budaya belajar pada masyarakat. Saat ini pemanfaatan fasilitas publik seperti museum kurang diminati. Selain itu, museum dengan konsep interaktif masih sedikit di Indonesia sehingga tema museum seni dan musik interaktif diajukan sebagai respon perancangan. Perancangan ini menggunakan pendekatan arsitektur perilaku. Selain itu, pendekatan romantik diterapkan sebagai sarana penyampaian makna dan pendekatan intelektual sebagai pendukung teknis.

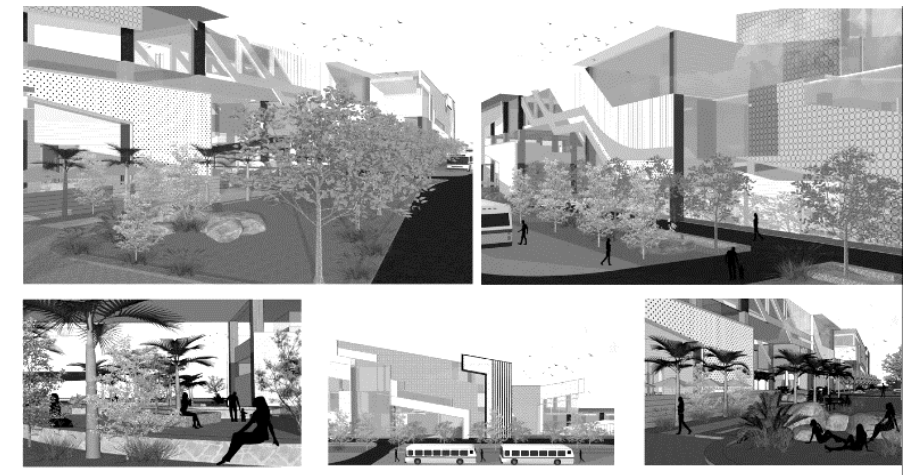

Gambar 15. Eksplorasi Formal (Eksplorasi Fasad dan Integrasi Ruang Luar)

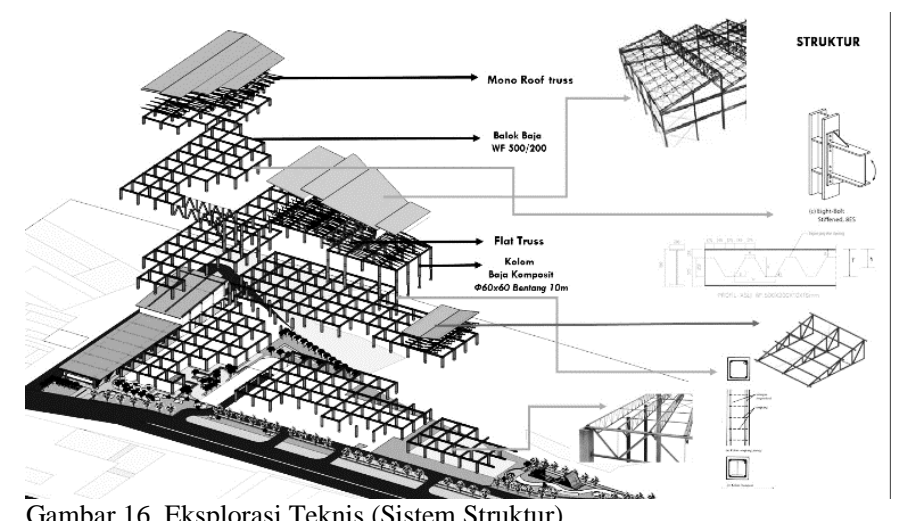

Gambar 16. Eksplorasi Teknis (Sistem Struktur)
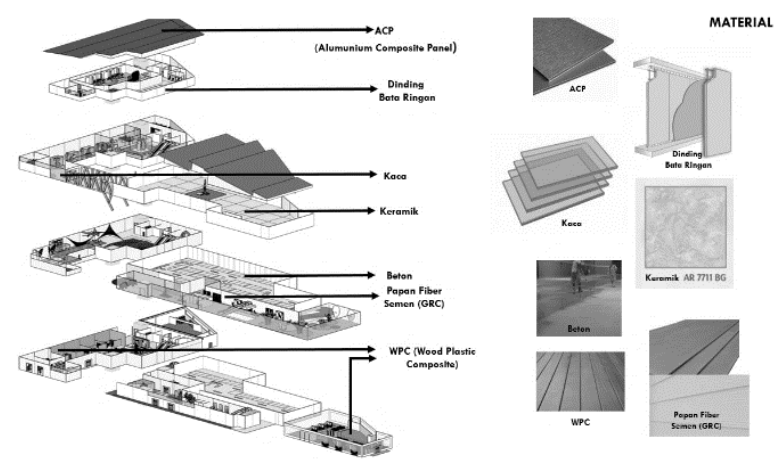

Gambar 17. Eksplorasi Teknis (Penggunaan Material)
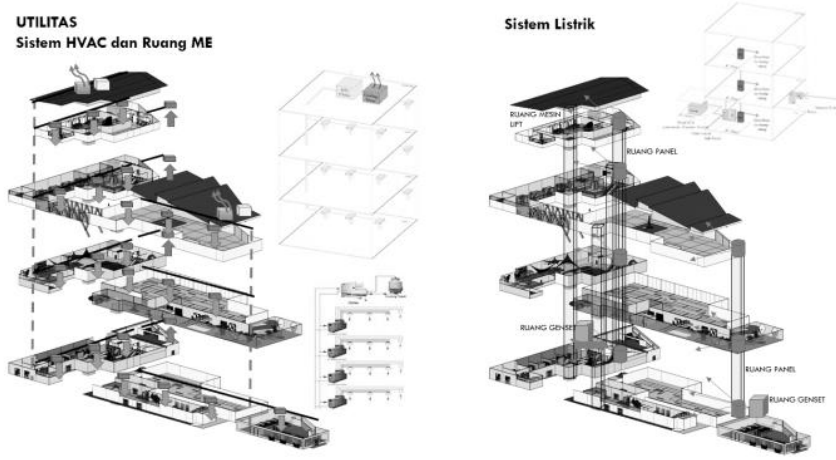

Gambar 18. Eksplorasi Teknis (Sistem Penghawaan dan Penyaluran Listrik) 
Metode yang digunakan adalah metode pemrograman untuk memetakan bentuk perilaku dan metode teknis estetis untuk menciptakan suasana tematik yang dicapai. Secara formal, keseluruhan aspek konsep berfokus pada eksplorasi isu; eksplorasi bentuk; dan eksplorasi makna. Secara teknis, perwujudan museum menggunakan standart dan ketentuan yang telah ada. Secara keseluruhan, tulisan ilmiah ini menjelaskan dan merumuskan proses perancangan Museum Seni dan Musik Interaktif dari proses merancang aspek formal sampai dengan aspek teknis yang berbasis perilaku belajar.
DAFTAR PUSTAKA

[1] I. Altman, The Environment and Social Behavior. New York: Irving Publisher Inc, 1981.

[2] W. M. Pena and S. A. Parshall, Problem Seeking: An Architectural Programming Primer. New York: John Wiley \& Sons Inc, 2001.

[3] H. Sanoff, Visual Research Methods in Design. New York: John Wiley \& Sons Inc, 1991.

[4] A. Chaplin, "The Architecture of Diagrams," 2014.

[5] P. K. L, Behavior Influence and Personality. New York: HoltRinehart \& Winston, 1973.

[6] E. Neufert, Data Arsitek, 2nd ed. Jakarta, 1990. 